\title{
Opposing Roles of BMP and TGF- $\beta$ Signaling Pathways in Pancreatitis: Mechanisms and Therapeutic Implication
}

\author{
Yanna Cao*, Madeline Drake, Joy Davis, Baibing Yang and Tien C Ko \\ Department of Surgery, The University of Texas Health Science Center, USA
}

Submission: August 21, 2019; Published: September 04, 2019

*Corresponding author: Yanna Cao, Department of Surgery, The University of Texas Health Science Center at Houston, 6431 Fannin Street, Houston, TX 77030, USA

\begin{abstract}
Bone morphogenetic proteins (BMPs) comprise a major subgroup of the transforming growth factor (TGF)- $\beta$ superfamily. They play pivotal roles in embryonic development and tissue homeostasis in adults. Deregulation of BMP and TGF- $\beta$ signaling contributes to developmental anomalies and multiple diseases. In this mini-review, we focus on BMP signaling in inflammatory disorders of the pancreas, acute and chronic pancreatitis, in contrast to TGF- $\beta$ signaling. We then discuss molecular mechanisms that interact with and connect between the BMP and TGF- $\beta$ signaling pathways. Lastly, we review potential implications of these molecular mechanisms for therapeutic development. In summary, BMP signaling pathway plays different roles during pancreatitis disease development, and the antagonism between BMP and TGF- $\beta$ signaling can be manipulated for therapeutic development against pancreatitis.
\end{abstract}

Keywords: Bone morphogenetic protein; Transforming growth factor-beta; Gremlin 1; Pancreatitis; Acute; Chronic; Inflammation; Fibrosis; Pancreatic stellate cells; Antibody

Abbreviations: BMP: Bone Morphogenetic Protein; TGF- $\beta$ : Transforming Growth Factor-Beta; microRNA: Micro Ribonucleic Acid; ECM: Extracellular Matrix; AP: Acute Pancreatitis; CP: Chronic Pancreatitis

\section{Introduction}

Bone morphogenetic proteins (BMPs) constitute a major subgroup of the transforming growth factor (TGF)- $\beta$ superfamily, comprising 18 (several also named as growth differentiation factors) out of the total 33 members [1]. The TGF- $\beta / B M P$ superfamily plays pivotal roles in embryonic development and tissue homeostasis in adults. Deregulation of the TGF- $\beta$ / BMP signaling contributes to developmental anomalies and multiple diseases [1,2]. The TGF- $\beta$ /BMP superfamily signals through a complex of membrane-associated serine/threonine kinase receptors. In the canonical signaling pathway, BMP ligand binds to BMP receptors type I (BMPR1) and type II (BMPR2) on the cell surface and subsequently activates intracellular mediators Smad1/5/8 via phosphorylation [3]. In parallel, TGF- $\beta$ binds to TGF- $\beta$ receptors T $\beta$ RI and T $\beta$ RII and activates Smad2/3. The phosphorylated Smad1/5/8 or pSmad2/3 form complexes with Smad4, which translocates to the nucleus to regulate transcription of target genes [4,5]. Activation of specific Smads may lead to distinct or opposing biological outcomes, most notably in disease states [3,6,7]. Both BMP and TGF- $\beta$ also activate other non-canonical signaling pathways [8,9]. BMP signaling can be regulated at the extracellular, membrane, and intracellular level. The most investigated molecules that negatively regulate BMP signaling extracellularly are the BMP antagonists, which sequester BMPs and prevent their interaction with the cell surface receptors. Over 12 members of endogenous BMP antagonists have been identified to date $[3,10]$.

Lines of evidence demonstrate that BMP signaling has proinflammatory properties in bronchial epithelial cells during airway inflammation [11], in activated endothelial cells [12], and in atherosclerotic arteries [13]. Paradoxically, BMP signaling has anti-fibrogenic functions in several organs, including kidneys, lungs, and liver [14-16]. However, the role of BMP signaling in the pancreas, specifically within pancreatic inflammatory disease processes, is unclear.

In recent years, our group has focused on the role of BMP signaling in acute (AP) and chronic pancreatitis (CP), the highly 
debilitating and painful inflammatory diseases of the pancreas. While a majority of AP cases self-resolve, approximately 16\% progress to $\mathrm{CP}$ after repeated episodes of AP (RAP), mainly in patients with risk factors like alcohol and tobacco use $[17,18]$. CP is the \#1 cause of Type 3c Diabetes [19], and a major risk factor for pancreatic cancer, one of the most lethal cancer types [20]. Unfortunately, the standard care for pancreatitis lacks specific pharmacological therapies, and remains primarily supportive. Thus, there is a pressing need to identify key mechanisms contributing to the disease development and progression, in order to develop innovative therapeutic strategies for blocking and reversing the pancreatic destruction associated with $\mathrm{CP}$; ultimately, reducing the risk for developing diabetes and pancreatic cancer in these patients.

To understand the role of BMPs in AP, we utilized experimental animal and cell models, and revealed that BMP/Smad1/5 signaling is activated; inhibition of BMP signaling attenuates the disease severity, indicating a pro-inflammatory role of BMP signaling in AP [21]. The role of TGF- $\beta$ signaling is controversial, with both pro-inflammatory and anti-inflammatory roles reported [22]. However, due to a lack of availability of most human AP samples, our study regarding BMP signaling is only proof-of-concept. Much work is needed to establish clinical relevance by identifying secreted factors of the TGF- $\beta / \mathrm{BMP}$ superfamily from patient blood and pancreatic juice, in addition to further study of the mechanisms in experiment models.

Several studies from our group have demonstrated opposing roles of BMP and TGF- $\beta$ in CP. For instance, in pancreatic stellate cells, the key executive cells in pancreatic fibrosis, BMP2 alone does not induce extracellular matrix (ECM) expression but inhibits TGF- $\beta$ induced-ECM production [23]. Knockout of BMPR2 in mice exacerbates $\mathrm{CP}$, leading to enhanced inflammation and fibrosis, two hallmarks of CP [24]. These findings reveal a protective and anti-fibrogenic role of BMP signaling in $\mathrm{CP}$, in contrast to the pro-fibrogenic TGF- $\beta$ signaling $[25,26]$.

To search for molecular links between BMP and TGF- $\beta$, we focus on Gremlin1 (Grem1), a BMP antagonist, which has reported pro-fibrogenic function in several organs $[15,27,28]$. We demonstrated increased levels of Grem1 in human and mouse CP, associated with elevated TGF- $\beta$. TGF- $\beta$ can induce Grem1, and Grem1 can block BMP2 induced Smad1/5 signaling in pancreatic stellate cells. Knockout of Grem 1 in mice attenuates pancreatic fibrosis [29]. These findings propose a feed-forward loop between TGF- $\beta$, Grem1, and BMP, in which Grem1 may act as a nodal point between the pro-fibrogenic TGF- $\beta$ and the antifibrogenic BMP signaling pathways. Thus, the level of Grem1 expression may define the disease progression from AP, RAP, to CP (Figure 1).

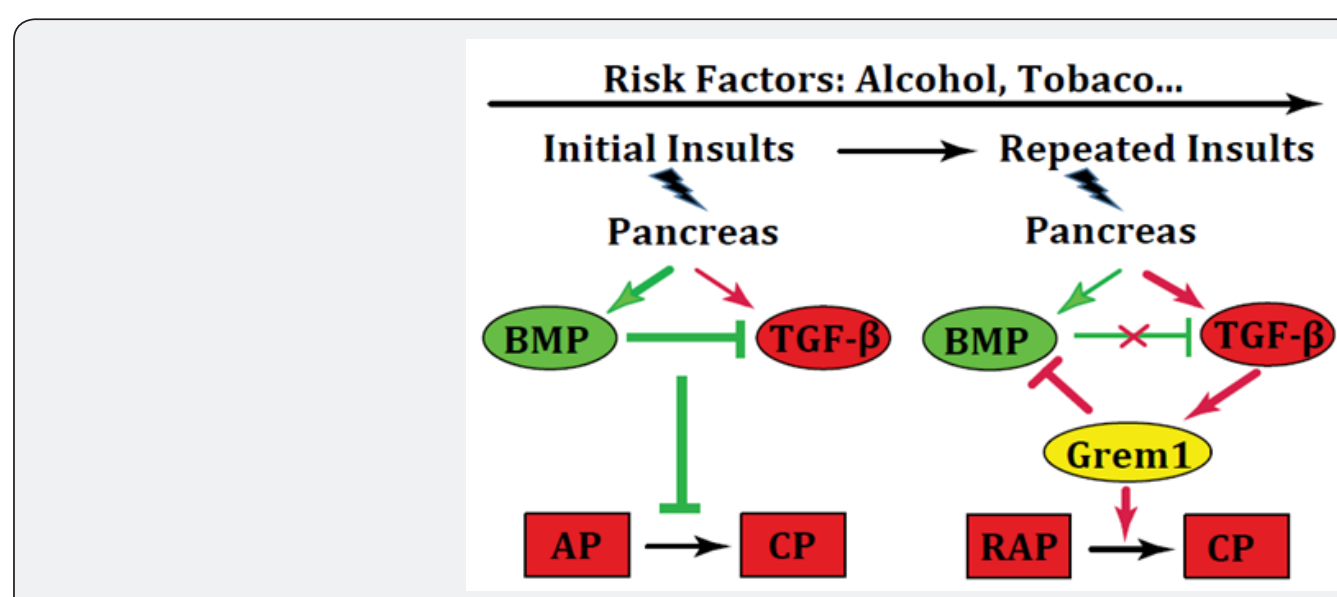

Figure 1: Proposed interaction between BMP, TGF- $\beta$, and Grem1 During AP to CP Progression.

Overall, temporal changes of the TGF- $\beta$ /BMP signaling molecules and Grem1 during disease progression from AP to CP $[23,24,29,30]$, provide rationale for further translational study. Since TGF- $\beta$ has a broad spectrum of biological functions, systemic TGF- $\beta$ blockade may yield unexpected or detrimental effects. To circumvent these effects, modulation of TGF- $\beta$ downstream mediators and of the opposing BMP signaling that desensitize cellular responses to TGF- $\beta$ or antagonize TGF- $\beta$ signal transduction should be explored. Thus, the therapeutic goal is to restore or up-regulate the anti-fibrogenic BMP signaling pathway and to counteract the pro-fibrogenic TGF- $\beta$ signaling pathway. This can be executed by time-dependently administering the Grem1 neutralization antibody [31] or specific microRNAs $[32,33]$ that can inhibit Grem1 as well as release suppression on BMP signaling, or in combination with the specific small molecules or peptides that can activate BMP signaling $[34,35]$.

\section{Conclusion}

Studies on the different roles and the reciprocal regulation of BMP and TGF- $\beta$ not only advance our knowledge on how the same superfamily members regulate each other's functions 
in diseased states, but also provide insights on how the antagonistic roles of BMP and TGF- $\beta$ signaling can be modulated as therapeutic approaches.

\section{Acknowledgements}

This study was supported by the National Institute of Health grant 1 R21 AA027014-01A1 (T.C.K.) and Jack H Mayfield M.D. Distinguished Professorship in Surgery (T.C.K).

\section{References}

1. Morikawa M, Derynck R, Miyazono K (2016) TGF-beta and the TGFbeta Family: Context-Dependent Roles in Cell and Tissue Physiology. Cold Spring Harb Perspect Biol 8(5).

2. Yu Y, Feng XH (2019) TGF-beta signaling in cell fate control and cancer Curr Opin Cell Biol 61: 56-63.

3. Ye L, Lewis-Russell JM, Kyanaston HG, Jiang WG (2007) Bone morphogenetic proteins and their receptor signaling in prostate cancer. Histol Histopathol 22(10): 1129-1147.

4. Derynck R, Feng XH (1997) TGF-beta receptor signaling. Biochim Biophys Acta 1333(2): F105-150.

5. Massague J (2012) TGF beta signalling in context. Nat Rev Mol Cell Biol 13(10): 616-630.

6. Hudnall AM, Arthur JW, Lowery JW (2016) Clinical Relevance and Mechanisms of Antagonism Between the BMP and Activin/TGF-beta Signaling Pathways. J Am Osteopath Assoc 116(7): 452-461.

7. Ning J, Zhao Y, Ye Y, Yu J (2019) Opposing roles and potential antagonistic mechanism between TGF-beta and BMP pathways: Implications for cancer progression. E Bio Medicine 41: 702-710.

8. Ten Dijke P, Korchynskyi O, Valdimarsdottir G, Goumans MJ (2003) Controlling cell fate by bone morphogenetic protein receptors. Mol Cell Endocrinol 211(1-2): 105-113.

9. Zhang YE (2009) Non-Smad pathways in TGF-beta signaling. Cell Res 19(1): 128-139.

10. Brazil DP, Church RH, Surae S, Godson C, Martin F (2015) BMP signalling: agony and antagony in the family. Trends Cell Biol 25(5): 249-264.

11. Rosendahl A, Pardali E, Speletas M, Ten Dijke P, Heldin CH, et al. (2002) Activation of bone morphogenetic protein/Smad signaling in bronchial epithelial cells during airway inflammation. Am J Respir Cell Mol Biol 27(2): 160-169.

12. Csiszar A, Ahmad M, Smith KE, Labinskyy N, Gao Q et al. (2006) Bone morphogenetic protein-2 induces proinflammatory endothelial phenotype. Am J Pathol 168(2): 629-638.

13. Dhore CR, Cleutjens JP, Lutgens E, Cleutjens KB, Geusens PP, et al (2001) Differential expression of bone matrix regulatory proteins in human atherosclerotic plaques. Arterioscler Thromb Vasc Biol 21(12): 1998-2003.

14. Zeisberg M, Hanai J, Sugimoto H, Mammoto T, Charytan D, et al. (2003) BMP-7 counteracts TGF-beta1-induced epithelial-to-mesenchymal transition and reverses chronic renal injury. Nat Med 9(7): 964-968.

15. Myllarniemi M, Lindholm P, Ryynanen MJ, Kliment CR, Salmenkivi K, et al. (2008) Gremlin-mediated decrease in bone morphogenetic protein signaling promotes pulmonary fibrosis. Am J Respir Crit Care Med 177(3): 321-329.

16. Kinoshita K, Iimuro Y, Otogawa K, Saika S, Inagaki Y, et al. (2007) Adenovirus-mediated expression of BMP-7 suppresses the development of liver fibrosis in rats. Gut 56(5): 706-714.
17. Lankisch PG, Breuer N, Bruns A, Weber-Dany B, Lowenfels AB, et al. (2009) Natural history of acute pancreatitis: a long-term populationbased study. Am J Gastroenterol 104(11): 2797-2805.

18. Kleeff J, Whitcomb DC, Shimosegawa T, Esposito I, Lerch MM (2017) Chronic pancreatitis. Nature reviews Disease primers 3: 17060.

19. Hart PA, Bellin MD, Andersen DK, Bradley D, Cruz-Monserrate Z, et al. (2016) Type 3c (pancreatogenic) diabetes mellitus secondary to chronic pancreatitis and pancreatic cancer. Lancet Gastroenterol Hepatol 1(3): 226-237.

20. Ryan DP, Hong TS, Bardeesy N (2014) Pancreatic adenocarcinoma. N Engl J Med 371(11): 1039-1049.

21. Cao Y, Yang W, Tyler MA, Gao X, Duan C, et al. (2013) Noggin Attenuates Cerulein-Induced Acute Pancreatitis and Impaired Autophagy. Pancreas 42(2): 301-307.

22. Zhou Q, Xia S, Guo F, Hu F, Wang Z, et al. (2019) Transforming growth factor-beta in pancreatic diseases: Mechanisms and therapeutic potential. Pharmacol Res 142: 58-69.

23. Gao X, Cao Y, Yang W, Duan C, Aronson JF, et al. (2013) BMP2 inhibits TGF-beta-induced pancreatic stellate cell activation and extracellular matrix formation. Am J Physiol Gastrointest Liver Physiol 304(9): G804-813.

24. Gao X, Cao Y, Staloch DA, Gonzales MA, Aronson JF, et al. (2014) Bone morphogenetic protein signaling protects against cerulein-induced pancreatic fibrosis. PLoS One 9(2): e89114.

25. Nagashio Y, Ueno H, Imamura M, Asaumi H, Watanabe S, et al. (2004) Inhibition of transforming growth factor beta decreases pancreatic fibrosis and protects the pancreas against chronic injury in mice. Lab Invest 84(12): 1610-1618.

26. Vogelmann R, Ruf D, Wagner M, Adler G, Menke A (2001) Effects of fibrogenic mediators on the development of pancreatic fibrosis in a TGF-beta1 transgenic mouse model. Am J Physiol Gastrointest Liver Physiol 280(1): G164-172.

27. Carvajal G, Droguett A, Burgos ME, Aros C, Ardiles L, et al. (2008) Gremlin: a novel mediator of epithelial mesenchymal transition and fibrosis in chronic allograft nephropathy. Transplant Proc 40(3): 734739.

28. Boers W, Aarrass S, Linthorst C, Pinzani M, Elferink RO, et al. (2006) Transcriptional profiling reveals novel markers of liver fibrogenesis: gremlin and insulin-like growth factor-binding proteins. J Biol Chem 281(24): 16289-16295.

29. Staloch D, Gao X, Liu K, Xu M, Feng X, et al. (2015) Gremlin is a key pro-fibrogenic factor in chronic pancreatitis. J Mol Med (Berl) 93(10): 1085-1093.

30. Rastellini C, Han S, Bhatia V, Cao Y, Liu K, et al. (2015) Induction of chronic pancreatitis by pancreatic duct ligation activates BMP2, apelin, and PTHrP expression in mice. Am J Physiol Gastrointest Liver Physiol 309(7): G554-565.

31. Ciuclan L, Sheppard K, Dong L, Sutton D, Duggan N, et al. (2013) Treatment with anti-gremlin 1 antibody ameliorates chronic hypoxia/ SU5416-induced pulmonary arterial hypertension in mice. Am J Pathol 183(5): 1461-1473.

32. Graham JR, Williams CM, Yang Z (2014) MicroRNA-27b Targets Gremlin 1 to Modulate Fibrotic Responses in Pulmonary Cells. J Cell Biochem 115(9): 1539-1548.

33. Yu P, Liu K, Gao X, Karmouty-Quintana H, Bailey JM, et al. (2018) Transforming Growth Factor-beta and Bone Morphogenetic Protein 2 Regulation of MicroRNA-200 Family in Chronic Pancreatitis. Pancreas 47(2): 252-256. 
34. Lepparanta 0, Tikkanen JM, Bespalov MM, Koli K, Myllarniemi M (2013) Bone morphogenetic protein-inducer tilorone identified by high-throughput screening is antifibrotic in vivo. Am J Respir Cell Mol Biol 48(4): 448-455.
35. Sugimoto H, LeBleu VS, Bosukonda D, Keck P, Taduri G, et al. (2012) Activin-like kinase 3 is important for kidney regeneration and reversal of fibrosis. Nat Med 18(3): 396-404.

Your next submission with JuniperPublishers
will reach you the below assets
- Quality Editorial service
- Swift Peer Review
- Reprints availability
- E-prints Service
- Manuscript Podcast for convenient understanding
- Global attainment for your research
- Manuscript accessibility in different formats
( Pdf, E-pub, Full Text, audio)
- Unceasing customer service
Track the below URL for one-step submission
https://juniperpublishers.com/online-submission.php

